\title{
Living with the African Honey Bee ${ }^{1}$
}

\author{
J. D. Ellis and M. Bammer, ${ }^{2}$
}

\section{Introduction}

African honey bees and European honey bees are the same species of honey bee (Apis mellifera), but the two are classified as different subspecies or races of honey bee. European honey bees (the honey bees most familiar to Americans) were first introduced to the Americas in the 1500s by European explorers. For centuries, European honey bees have been selected by beekeepers for their robust honey production and storage behavior, their reduced regular swarming (colony splitting) tendencies, and their gentleness. The African honey bee was brought to Brazil in the 1950s in an effort to increase honey production there. However, some queens were accidentally released and thrived in Brazil's environment. Since then, African bees have spread throughout South America, Central America, and into the southwestern United States and Florida. The African honey bee is considerably more defensive than its European honey bee cousin. African honey bee x European honey bee hybrids present an unpredictable combination of both European honey bee and African honey bee behavioral traits, and this unpredictability warrants the understanding of the true African bee and their behavior. For more information see African Honey Bee, Africanized Honey Bee, Killer Bee, Apis mellifera scutellata Lepeletier (Insecta: Hymenoptera: Apidae) and Differences Between European and African Honey Bees.

\begin{abstract}
African honey bees: What's in a name? In popular literature, "African," "Africanized," and "killer" bees are terms that have been used to describe the same honey bee. However, "African bee" or "African honey bee" most correctly refers to Apis mellifera scutellata when it is found outside of its native range. A.m. scutellata is a subspecies or race of honey bee native to sub-Saharan Africa, where it is referred to as "Savannah honey bee." Many subspecies of African honey bee thrive in the region, making the term "African honey bee" too ambiguous in Africa. The term "Africanized honey bee" refers to hybrids between A.m. scutella and one or more of the European subspecies of honey bees kept in the Americas. There is remarkably little introgression of European honey bee genes into the introduced A.m. scutellata population throughout South America, Central America, and Mexico. Thus, it is more precise to refer to the population of African honey bees present in the Americas as "African-derived honey bees." However, for the sake of simplicity/ consistency, we will refer to African-derived honey bees outside of their native range as "African honey bees," or "AHBs."
\end{abstract}

\section{Defensive Behavior}

All honey bees are defensive, meaning that if their colonies are disturbed by people or animals, bees will come out of their nests to defend against the possible intruder. Generally speaking, European honey bees may send out up to a few dozen bees in response to a disturbance that occurs as far as 20 feet from the nest. In contrast, an African honey bee colony may send out several hundred bees (or even thousands) in response to a disturbance that occurs as far as 40 yards from the nest. In addition, AHBs may pursue the possible intruder for 400 yards or more. Their defensive behavior is an evolutionary response to their many biological competitors, including honey badgers, bee eaters, and humans, in their native range. In contrast, the European honey bee population has been selected by beekeepers for

1. This document is ENY-170, one of a series of the Department of Entomology and Nematology, UF/IFAS Extension. Original publication date March 2018. Visit the EDIS website at http://edis.ifas.ufl.edu.

2. J. D. Ellis, associate professor; and M. Bammer, Extension coordinator, Department of Entomology and Nematology; UF/IFAS Extension, Gainesville, FL 32611.

The Institute of Food and Agricultural Sciences (IFAS) is an Equal Opportunity Institution authorized to provide research, educational information and other services only to individuals and institutions that function with non-discrimination with respect to race, creed, color, religion, age, disability, sex, sexual orientation, marital status, national origin, political opinions or affiliations. For more information on obtaining other UF/IFAS Extension publications, contact your county's UF/IFAS Extension office. 
manageable traits (gentleness, reduced swarming, high honey production-Table 1). Consequently, the European honey bee is gentler and more predictable behaviorally than is the African honey bee, though colonies of European honey bees can exhibit heightened defensive behavior under certain circumstances. Also, while most honey bees nest in enclosed areas (i.e. cavities), African honey bees have been known to nest in the open and near humans.

\section{African Honey Bees in Florida}

The first documentation of African honey bees in the state of Florida came in 2001 near the Port of Tampa. By 2003, African bees had established colonies in and around the Tampa area and since have spread throughout the southern half of the state, hybridizing with local European honey bee populations. Although some humans do get stung by African bees every year, most sting victims are pets and domestic animals because they are unable to escape tethering, corrals, kennels, etc. while being attacked.

The Florida Department of Agriculture and Consumer Services Division of Plant Industry (FDACS-DPI) has an Apiary Inspection Section with apiary inspectors disbursed throughout the state. The Apiary Inspection Section monitors the spread of African honey bees throughout Florida. Thanks to these monitoring programs, the public has a better understanding of the movement of African honey bees in the United States.

All beekeepers in the state of Florida must register with FDACS-DPI and follow best management requirements (BMRs) for maintaining European honey bees (Table 1). These guidelines help ensure bees in managed bee yards remain European. Beekeepers closely following the BMRs are not keeping African honey bees. Also, registered beekeepers have their hives checked by state apiary inspectors at regular intervals. It is recommended that defensive colonies be requeened to ensure that the bees remain European. For more information see Explaining the Best Management Practices for Maintaining European Honey Bee Colonies.

African honey bee training programs have been implemented around the state to provide training for first responders and pest control operators (PCO-Table 1). This training is offered so that both groups will know how to respond to a bee attack should one occur. For more information see Removal of Swarms and Colonies for Pest Control Operators.

\section{What You Can Do}

Education about African honey bees can be one of the best defenses against misinformation about them. Understanding the behavioral differences between European and African honey bees is critical to understanding African honey bees and what one must do if an African honey bee nest is encountered.

\section{Understand the difference between foraging bees and} colonies of bees. A scattered assemblage of bees buzzing around flowers or drinking from puddles should be of no concern to the passerby. They are typically not defensive. For large groups of bees massed together and not foraging, see point 2 below.

\section{Exercise caution if you see a swarm or colony,} especially if you live in an area where African honey bees are present (Table 1). Many people decide not to do anything about a feral colony (Table 1) because "the bees seem calm," but a small, calm colony left unmanaged can become larger and more aggressive as it gets established. Established colonies are more defensive because the bees have a nest to protect. The state of Florida recommends that all feral honey bee colonies (i.e. those not managed by beekeepers) nesting in close proximity to areas frequented by people or domestic animals be either (1) removed from the nest site by a registered beekeeper or trained Pest Control Operator (Table 1) or (2) eradicated by a licensed PCO. Consult the publication Choosing the Right Pest Control Operator for Honey Bee Removal: A Consumer Guide for advice on choosing a PCO. It is the responsibility of the property owner to deal with an unwanted swarm or colony of honey bees. To find a registered beekeeper or PCO who offers removal or eradication services, visit: http://www.freshfromflorida.com/ Business-Services/Bees-Apiary/Florida-Bee-Protection/ Bee-Removal-or-Eradication-in-Florida. For information on honey bee swarms see Swarm Control for Managed Beehives.

3. "Bee-proof" your home and property. "Bee-proofing" means methodically removing or restricting access to potential honey bee nesting sites. This practice is beneficial for many reasons. Naturally, if an area is bee-proof, the potential for feral colonies (Table 1) to move into that area is greatly lowered; therefore, the risk of stinging incidents is also lowered. In addition, colonies that establish themselves inside a wall or around a structure can cause significant property damage and require removal. This process can be expensive and often requires additional structural repair, which also costs 
time and money. Bee-proofing is an ongoing process that requires an initial assessment to address a majority of the sites on a property as well as follow-up inspections to maintain the bee-proofed area. For information on how to bee-proof your home or property, see Bee-proofing for Florida Citizens.

\section{Develop and review a bee safety plan with your family:}

- Listen for buzzing and look for bees entering or leaving an area, indicating a nest or swarm is nearby (Table 1).

- Carefully enter areas where bees might be nesting (garages, sheds, grills, old cars, etc.).

- Examine areas before using noisy power equipment (lawn mowers, blowers, chain saws, etc.).

- Examine areas for nesting colonies before tying or penning pets and livestock.

- Never disturb a swarm or colony of bees (Table 1).

5. Be prepared for an allergic reaction. If you know that you are allergic to bee stings, obtain a prescription from your doctor for an Epi-pen and carry it with you at all times. Consider informing others of your allergy when engaging in outdoor activities so that they can respond appropriately if you are stung.

\section{If You Encounter a Swarm or Colony}

First, do not disturb the bees.

Honey bee swarms (both African and European-Table 1) are generally docile and not defensive because they do not yet have a nest to protect. Regardless, never approach a honey bee swarm because one cannot be sure that it is only a swarm rather than a newly established colony.

An untrained individual should never disturb a colony of bees. Property owners may choose to have a swarm or colony removed alive by a beekeeper who is registered by the state of Florida or they may contact a PCO to perform eradication or removal (Table 1).

If a swarm or colony is disturbed:

- Get away from bees as quickly as possible-run!

- Run in a straight line to shelter.

- Protect your face and airways as you run away. Honey bees are attracted to hair and dark colors (e.g. eyes, open mouth, nostrils).

- Take shelter in an enclosed area (shed, house, vehicle, etc.).
- Do not jump into water or hide in bushes.

- Do not swat at the bees; rapid movements will agitate them further.

- Call 911 if someone is being attacked.

- Contact a trained and registered beekeeper or PCO to remove or eradicate the colony (Table 1).

Foraging bees gathering nectar, pollen, water, or plant resin should be of no concern to the passerby. They are typically not defensive because they are away from their nest.

\section{If You Are Stung}

All female worker honey bees, including African honey bees, can only sting once. The bee's stinger remains in the victim when she flies away, and she dies soon afterward. African honey bees have a lower defensive threshold than do European honey bees. They respond to smaller stimuli and in greater numbers than do their European counterparts. Their venom is no more toxic than that of European honey bees. They simply respond in greater numbers, often attacking in groups of hundreds or thousands of bees, when their nests are disturbed.

If you are stung by a honey bee:

1. Remove the stinger(s) from your skin as soon as possible. Stingers will continue to inject venom until they are removed or exhausted. It does not matter how you remove the stinger(s); the important thing is to remove them as quickly as possible.

2. Wash sting sites with soap and water to prevent infection and apply ice to relieve pain and swelling.

3. Call 911 and/or seek emergency medical attention immediately if you experience an allergic reaction. Symptoms of an allergic reaction can include difficulty breathing, hives covering large areas of the body, nausea, vomiting, and/or swelling away from the sting site(s). The latter suggests a systemic reaction.

4. Seek medical attention if you are stung numerous times: there is a risk of toxic envenomation (bee venom overdose) after about 5-10 stings/pound of body weight, Remember that swelling around the stung area is normal and not an indication of systematic allergy. 


\section{Selected References}

Ellis, J. D., and A. Ellis. 2009. African Honey Bee, Africanized Honey Bee, Killer Bee, Apis mellifera scutellata Lepeletier (Insecta: Hymenoptera: Apidae). EENY-429. Gainesville: University of Florida Institute of Food and Agricultural Sciences. http://edis.ifas.ufl.edu/in790

Table 1. Terms.

\begin{tabular}{|l|l|}
\hline Swarm & $\begin{array}{l}\text { A swarm is honey bee reproduction at the colony level. When a honey bee colony grows in population, about } \\
\text { 30-60\% of the bees will leave with the queen in search of another suitable nesting site. After leaving the original } \\
\text { nest site, the bees coalesce into a cluster in a specific area, waiting there until they find a suitable home to which } \\
\text { they fly. The bees remaining in the original colony will produce a new queen. The part of the colony that left the } \\
\text { original nest site is called a "swarm." The process of leaving the original nest site and moving to a new one is called } \\
\text { "swarming." }\end{array}$ \\
\hline Feral colony & $\begin{array}{l}\text { A colony of honey bees nesting outside a managed hive. These colonies may be found nesting in many different } \\
\text { locations: trees, abandoned buildings, soffits, garages, and other protected spots. These bees are referred to as feral } \\
\text { rather than wild because they or their direct ancestors originated from a managed hive. Honey bees were brought } \\
\text { to the United States by humans, so no true wild colonies exist here. They can be "wild" only where they are native. }\end{array}$ \\
\hline $\begin{array}{l}\text { Pest control operator } \\
\text { (PCO) }\end{array}$ & $\begin{array}{l}\text { A pest control operator is an individual who works as a licensed professional, either for him/herself or for a } \\
\text { professional pest management company. Many of them are trained to handle honey bee removals. }\end{array}$ \\
\hline Registered beekeeper & $\begin{array}{l}\text { A registered beekeeper owns and operates European honey bee colonies and is registered as a beekeeper under } \\
\text { Florida State Statute 5B-.54.0105 with the Florida Department of Agriculture and Consumer Services. Registered } \\
\text { beekeepers are permitted to remove honey bee colonies or swarms provided they use no pesticides }\end{array}$ \\
\hline
\end{tabular}

O’Malley, M. K., J. D. Ellis, and C. M. Zettel Nalen. 2009. Differences between European and African Honey Bees. Food and Agricultural Sciences. http://edis.ifas.ufl.edu/ in784 EENY-147. Gainesville: University of Florida Institute of 